\title{
EFFICIENCY OF BIOLOGICAL TREATMENT FOR THE REMOVAL OF TOTAL AND THERMOTOLERANT COLIFORM BACTERIA FROM DOMESTIC SEWAGE
}

\author{
EFICIÊNCIA DO TRATAMENTO BIOLÓGICO NA REMOÇÃO DE COLIFORMES \\ TOTAIS E TERMOTOLERANTES EM ESGOTO HUMANO
}

\begin{abstract}
Paula Maria Pilotto BRANCO ${ }^{1}$; Ricardo Galbiatti Sandoval NOGUEIRA ${ }^{2}$; Lívia Maria Soares FERREIRA ${ }^{3}$; Luiz Augusto do AMARAL ${ }^{4}$; Jorge de LUCAS JÚNIOR ${ }^{5}$

1. Médica Veterinária, Doutoranda em Medicina Veterinária, Departamento de Medicina Veterinária Preventiva e Reprodução Animal, Faculdade de Ciências Agrárias e Veterinárias - FCAV, Universidade Estadual Paulista - UNESP, Jaboticabal, SP, Brasil. paulapilotto@hotmail.com; 2. Zootecnista, Doutorando em Zootecnia, Faculdade de Zootecnia e Engenharia de Alimentos - FZEA, Universidade de São Paulo - USP Pirassununga, SP, Brasil; 3. Zootecnista, Mestre em Zootecnia - FCAV - UNESP, Jaboticabal, SP, Brasil; 4. Professor Adjunto, Departamento de Medicina Veterinária Preventiva e Reprodução Animal - FCAV - UNESP, Jaboticabal, SP, Brasil; 5. Professor Titular, Departamento de Engenharia Agrícola - FCAV - UNESP Jaboticabal, SP, Brasil.
\end{abstract}

\begin{abstract}
Researchers around the world have focused their efforts on devising combinations of technologies that are not only economically feasible but also effective in mitigating the impacts caused by wastes containing pathogens that pose potential risks to human and animal health. The purpose of this study was to evaluate the performance of a biological treatment system for removing total and thermotolerant coliform bacteria with a view to the possible organic recycling of domestic sewage. To this end, a tubular continuous flow anaerobic digester, with hydraulic retention time (HRT) of 25 days and an optional stabilization pond, were used to treat the sewage produced by 150 people in the municipality of Sertãozinho, SP, Brazil. The samples were collected weekly, always on the same day, at three different sampling points (inlet of the treatment system, the outlet of tubular digester, and the optional stabilization pond), totaling 108 samples. The MPN method was employed to determine the total coliform and thermotolerant coliform populations, using multiple series of three tubes (APHA, 2005). The system proved efficient in reducing the number of indicator bacteria of fecal contamination, showing a removal efficiency of $98.76 \%$ for total coliforms and of $99.29 \%$ for thermotolerant coliforms. However, a third treatment step involving polishing should be included to render the effluent suitable for use in fertigation or discharge into water bodies.
\end{abstract}

KEYWORDS: Continuous flow anaerobic digester. Environmental sustainability. Indicator bacteria. Sewage. Stabilization pond.

\section{INTRODUCTION}

The inconvenience caused by waste from domestic sewage systems and the pathogenic potential of some microorganisms to human and animal health (MARIN et al., 2015) pose a serious problem in today's context. To ensure environmental sustainability, many researchers have sought to devise combinations of efficient systems that can ensure human development while preserving the environment. The improper disposal of such effluents (whether human or animal) without any type of prior treatment may lead to the contamination of water, soil and air.

The careless use of natural resources and the discharge of untreated sewage in open ditches and water bodies is still a reality in many parts of Brazil today. According to Colon et al. (2015), the transmission of pathogens by the fecal-oral route is the main factor responsible for the deaths of more than $50 \%$ of children in developing countries. Thus, in most cases, the pollution of freshwater sources is the main cause of waterborne diseases. Food and water contamination by fecal matter causes up to 2.5 billion cases of diarrhea in children every year, and kills 600,000 of them (BMGF, 2011).

This paper proposes the use of a continuous flow anaerobic digestion system as a way to mitigate the environmental impacts resulting from the ineffective treatment or often the complete absence of proper treatment of human waste. This system has proved to be an attractive technology to treat animal wastes in developing countries (KINYUA et al., 2016), since it enables nutrients to be recycled, producing as byproducts biofertilizer, which can be used to replace mineral fertilizers, and biogas, a composition of gases, particularly $\mathrm{CH}_{4}$ and $\mathrm{CO}_{2}$, which can replace fossil fuels.

In this study, a biological system consisting of a tubular continuous flow anaerobic digester and an optional stabilization pond for sewage treatment were tested to evaluate the system's efficiency in reducing indicator bacteria of fecal contamination (total and thermotolerant coliforms) and the 
feasibility of discarding the effluent into the ground or discharging it into water bodies.

\section{MATERIAL AND METHODS}

The experiment was conducted in the municipality of Sertãozinho, SP, Brazil, using a continuous flow anaerobic digester with a volume of $152 \mathrm{~m}^{3}$ and a hydraulic retention time (HRT) of 25 days, as well as an optional stabilization pond, to treat the domestic sewage produced by 150 people. Samples were collected weekly, always on the same day, at three different sampling points: at the inlet of the treatment system, the outlet of the digester, and in the stabilization pond, totaling 108 samples. The samples were collected in duplicate, as follows: Influent - raw sewage; Effluent - outlet of the digester; stabilization pond, and immediately sent to the Biomass Lab I of the São Paulo State University at Jaboticabal for microbiological testing within no more than 24 hours. Total and thermotolerant coliform populations were determined by the MPN (most probable number) method, using multiple series of three tubes (APHA, 2005). This involved a presumptive test in a culture of lauryl sulfate tryptose broth, and incubation at $35^{\circ} \mathrm{C}$ for 24 to 48 h. The confirmatory test involved cultures in brilliant green bile broth, and incubation at $35^{\circ} \mathrm{C}$ for 24 to $48 \mathrm{~h}$ for total coliforms, and in E.C. broth with incubation at $44.5^{\circ} \mathrm{C}$ for $24 \mathrm{~h}$ for thermotolerant coliforms. A statistical analysis was performed by means of the Tukey test at a $5 \%$ level of significance.

\section{RESULTS AND DISCUSSION}

During the 18-week sampling period, the average bacterial population found in the influent was $1.82 \times 10^{8} \mathrm{MPN} 100 \mathrm{~mL}^{-1}$ of total coliforms and $2.60 \times 10^{7}$ MPN $100 \mathrm{~mL}^{-1}$ of thermotolerant coliforms (Table 1). Souza et al. (2015) observed similar values for total and thermotolerant coliforms, i.e., $3.22 \times 10^{8}$ and $2.62 \times 10^{7} \mathrm{MPN} 100$ $\mathrm{mL}^{-1}$, respectively, during a one-year monitoring period of a domestic sewage treatment system.

Table 1. Most probable number (MPN $100 \mathrm{~mL}^{-1}$ ) of total and thermotolerant coliforms in the influent and effluent of the digester, and removal rate $(\%)$ in the 18 -week period.

\begin{tabular}{ccccccc}
\hline \multirow{2}{*}{ Week } & \multicolumn{2}{c}{ Total coliforms $\left(\mathrm{MPN} 100 \mathrm{~mL}^{-1}\right.$ ) } & \multicolumn{2}{c}{ Thermotolerant coliforms (MPN $100 \mathrm{~mL}^{-1}$ ) } \\
\cline { 2 - 3 } & \multicolumn{2}{c}{ Sampling point } & Removal rate & \multicolumn{2}{c}{ Sampling point } & Removal \\
\cline { 2 - 5 } & Influent & Effluent & $(\%)$ & Influent & Effluent & rate $\%$ \\
\hline 0 & $2.05 \times 10^{6}$ & $1.06 \times 10^{6}$ & 48.20 & $1.05 \times 10^{6}$ & $5.62 \times 10^{5}$ & 46.48 \\
1 & $5.65 \times 10^{5}$ & $2.25 \times 10^{5}$ & 60.18 & $4.95 \times 10^{5}$ & $1.55 \times 10^{5}$ & 68.69 \\
2 & $2.40 \times 10^{8}$ & $9.70 \times 10^{4}$ & 99.96 & $1.16 \times 10^{8}$ & $9.70 \times 10^{4}$ & 99.92 \\
3 & $1.21 \times 10^{8}$ & $1.60 \times 10^{5}$ & 99.87 & $7.07 \times 10^{7}$ & $6.50 \times 10^{4}$ & 99.91 \\
4 & $1.20 \times 10^{8}$ & $1.40 \times 10^{4}$ & 99.99 & $1.10 \times 10^{8}$ & $6.15 \times 10^{3}$ & 99.99 \\
5 & $7.12 \times 10^{6}$ & $2.40 \times 10^{4}$ & 99.66 & $6.12 \times 10^{6}$ & $2.40 \times 10^{4}$ & 99.61 \\
6 & $1.26 \times 10^{9}$ & $1.11 \times 10^{6}$ & 99.91 & $1.50 \times 10^{6}$ & $1.05 \times 10^{4}$ & 99.30 \\
7 & $6.10 \times 10^{6}$ & $4.67 \times 10^{5}$ & 92.34 & $9.70 \times 10^{5}$ & $3.46 \times 10^{5}$ & 64.33 \\
8 & $2.10 \times 10^{5}$ & $1.55 \times 10^{4}$ & 92.62 & $9.70 \times 10^{4}$ & $1.10 \times 10^{4}$ & 88.66 \\
9 & $9.70 \times 10^{5}$ & $2.05 \times 10^{4}$ & 97.89 & $6.70 \times 10^{5}$ & $1.25 \times 10^{4}$ & 98.13 \\
10 & $1.90 \times 10^{6}$ & $1.60 \times 10^{4}$ & 99.16 & $1.65 \times 10^{6}$ & $1.20 \times 10^{4}$ & 99.27 \\
11 & $1.26 \times 10^{9}$ & $2.05 \times 10^{6}$ & 99.84 & $1.11 \times 10^{6}$ & $2.00 \times 10^{4}$ & 98.19 \\
12 & $2.05 \times 10^{6}$ & $5.25 \times 10^{5}$ & 74.39 & $1.70 \times 10^{6}$ & $1.05 \times 10^{4}$ & 99.38 \\
13 & $2.26 \times 10^{7}$ & $3.00 \times 10^{5}$ & 98.67 & $1.01 \times 10^{7}$ & $1.90 \times 10^{5}$ & 98.12 \\
14 & $1.09 \times 10^{7}$ & $1.16 \times 10^{5}$ & 98.93 & $6.55 \times 10^{5}$ & $2.05 \times 10^{4}$ & 96.87 \\
15 & $7.55 \times 10^{7}$ & $7.23 \times 10^{5}$ & 99.04 & $5.05 \times 10^{7}$ & $2.34 \times 10^{5}$ & 99.54 \\
16 & $1.39 \times 10^{8}$ & $4.75 \times 10^{5}$ & 99.66 & $9.40 \times 10^{7}$ & $2.04 \times 10^{5}$ & 99.78 \\
17 & $1.70 \times 10^{6}$ & $6.55 \times 10^{4}$ & 96.15 & $8.00 \times 10^{5}$ & $1.55 \times 10^{4}$ & 98.06 \\
\hline Average & $1.82 \times 10^{8}$ & $4.15 \times 10^{5}$ & 92.02 & $2.60 \times 10^{7}$ & $1.11 \times 10^{5}$ & 91.90 \\
\hline
\end{tabular}

The continuous flow anaerobic digestion process attained average removal rates of $93.63 \%$ and $88.48 \%$ of the total and thermotolerant coliform population, respectively. However, in their study of 
a biological treatment system composed of several stages, Souza et al. (2015) found lower total and thermotolerant coliform removal rates of $86.76 \%$ and $80.99 \%$, respectively, upon comparing the influent and effluent only in the first portion of the system, which consisted of a septic tank.

In Table 2, note that, upon entering the stabilization pond, the effluent from the digester presented a bacterial population of total and thermotolerant coliforms of $4.15 \times 10^{5}$ and $1.11 \times 10^{5}$ MPN $100 \mathrm{~mL}^{-1}$, respectively. After its 18-week dwell time in the stabilization pond, the effluent showed parameters of $2.13 \times 10^{4}$ and $1.23 \times 10^{4}$ MPN $100 \mathrm{~mL}^{-1}$. Therefore, the stabilization pond served as a complement in the biodigestion treatment and contributed to reduce the total and thermotolerant coliform population by 78.00 and $75.02 \%$, respectively.

Table 2. Most probable number (MPN $100 \mathrm{~mL}^{-1}$ ) of total and thermotolerant coliforms in the effluent of the digester and the stabilization pond, and removal rate $(\%)$ in the 18 -week period.

\begin{tabular}{ccccccc}
\hline \multirow{2}{*}{ Week } & \multicolumn{2}{c}{ Total coliforms (MPN $100 \mathrm{~mL}^{-1}$ ) } & \multicolumn{2}{c}{ Thermotolerant coliforms (MPN $\left.100 \mathrm{~mL}^{-1}\right)$} \\
\cline { 2 - 3 } & \multicolumn{2}{c}{ Sampling point } & Removal rate & \multicolumn{2}{c}{ Sampling point } & $\begin{array}{c}\text { Removal } \\
\text { rate }(\%)\end{array}$ \\
\cline { 2 - 3 } \cline { 5 - 6 } 0 & Effluent & Pond & & Effluent & Pond & \\
1 & $1.06 \times 10^{6}$ & $2.10 \times 10^{4}$ & 98.02 & $5.62 \times 10^{5}$ & $1.06 \times 10^{4}$ & 98.11 \\
2 & $2.25 \times 10^{5}$ & $9.10 \times 10^{4}$ & 59.56 & $1.55 \times 10^{5}$ & $1.45 \times 10^{4}$ & 90.65 \\
3 & $9.70 \times 10^{4}$ & $7.70 \times 10^{4}$ & 20.62 & $9.70 \times 10^{4}$ & $7.70 \times 10^{4}$ & 20.62 \\
4 & $1.60 \times 10^{5}$ & $5.55 \times 10^{4}$ & 65.31 & $6.50 \times 10^{4}$ & $2.90 \times 10^{4}$ & 55.38 \\
5 & $1.40 \times 10^{4}$ & $4.25 \times 10^{3}$ & 69.64 & $6.15 \times 10^{3}$ & $3.00 \times 10^{3}$ & 51.22 \\
6 & $2.40 \times 10^{4}$ & $1.40 \times 10^{4}$ & 41.67 & $2.40 \times 10^{4}$ & $1.17 \times 10^{4}$ & 51.46 \\
7 & $1.11 \times 10^{6}$ & $7.75 \times 10^{3}$ & 99.30 & $1.05 \times 10^{4}$ & $1.85 \times 10^{3}$ & 82.38 \\
8 & $4.67 \times 10^{5}$ & $7.75 \times 10^{3}$ & 98.34 & $3.46 \times 10^{5}$ & $7.65 \times 10^{3}$ & 97.79 \\
9 & $1.55 \times 10^{4}$ & $6.15 \times 10^{3}$ & 60.32 & $1.10 \times 10^{4}$ & $4.90 \times 10^{3}$ & 55.45 \\
10 & $2.05 \times 10^{4}$ & $1.25 \times 10^{4}$ & 39.02 & $1.25 \times 10^{4}$ & $9.25 \times 10^{3}$ & 26.00 \\
11 & $1.60 \times 10^{4}$ & $3.80 \times 10^{3}$ & 76.25 & $1.20 \times 10^{4}$ & $1.20 \times 10^{3}$ & 90.00 \\
12 & $2.05 \times 10^{6}$ & $7.75 \times 10^{3}$ & 99.62 & $2.00 \times 10^{4}$ & $2.05 \times 10^{3}$ & 89.75 \\
13 & $5.25 \times 10^{5}$ & $1.60 \times 10^{3}$ & 99.70 & $1.05 \times 10^{4}$ & $1.40 \times 10^{3}$ & 86.67 \\
14 & $3.00 \times 10^{5}$ & $2.10 \times 10^{4}$ & 93.00 & $1.90 \times 10^{5}$ & $1.75 \times 10^{4}$ & 90.79 \\
15 & $1.16 \times 10^{5}$ & $6.60 \times 10^{3}$ & 94.31 & $2.05 \times 10^{4}$ & $3.00 \times 10^{3}$ & 85.37 \\
16 & $7.23 \times 10^{5}$ & $3.25 \times 10^{4}$ & 95.50 & $2.34 \times 10^{5}$ & $1.80 \times 10^{4}$ & 92.31 \\
17 & $4.75 \times 10^{5}$ & $1.09 \times 10^{4}$ & 97.71 & $2.04 \times 10^{5}$ & $7.30 \times 10^{3}$ & 96.42 \\
\hline Average & $6.55 \times 10^{4}$ & $2.60 \times 10^{3}$ & 96.03 & $1.55 \times 10^{4}$ & $1.55 \times 10^{3}$ & 90.00 \\
\hline
\end{tabular}

An analysis of the overall performance of the continuous flow anaerobic digester and stabilization pond system (Table 3) revealed a $98.76 \%$ reduction of total coliforms and a $99.29 \%$ reduction of thermotolerant coliforms. Moura et al. (2011) reported the same performance after analyzing the treatment of domestic sewage in rural areas using a mini-treatment plant. The removal potential after all the stages of the treatment station evaluated by Souza et al. (2015) also achieved good efficiency rates of $98.6 \%$ and $99.3 \%$ for total and thermotolerant coliforms, respectively. Calijuri et al. (2009) achieved removal rates of $99.20 \%$ to $99.79 \%$ for total coliforms and of 99.72 to $99.99 \%$ for fecal coliforms in their treatment of domestic sewage in anaerobic and aerobic reactor systems, respectively.

In Table 4, note that the average populations of total and thermotolerant coliforms in the influent, in the effluent from the digester and in the optional stabilization pond differed statistically by the Tukey test at a probability of 5\%, indicating the efficiency of the two stages of the treatment. When combined with the continuous flow tubular digester, the stabilization pond contributed significantly to the biological treatment to reduce the microorganisms under study. 
Table 3. Most probable number (MPN $100 \mathrm{~mL}^{-1}$ ) of total and thermotolerant coliforms in the entire system, and removal rate $(\%)$ in the 18 -week period.

\begin{tabular}{ccccccc}
\hline \multirow{2}{*}{ Week } & \multicolumn{2}{c}{ Total coliforms (MPN $100 \mathrm{~mL}^{-1}$ ) } & \multicolumn{2}{c}{ Thermotolerant coliforms (MPN $\left.100 \mathrm{~mL}^{-1}\right)$} \\
\cline { 2 - 3 } & \multicolumn{2}{c}{ Sampling point } & Removal rate & \multicolumn{2}{c}{ Sampling point } & $\begin{array}{c}\text { Removal } \\
\text { rate }(\%)\end{array}$ \\
\cline { 2 - 3 } \cline { 5 - 6 } Influent & Pond & $(\%)$ & Influent & Pond & 98.99 \\
1 & $2.05 \times 10^{6}$ & $2.10 \times 10^{4}$ & 98.98 & $1.05 \times 10^{6}$ & $1.06 \times 10^{4}$ & 97.07 \\
2 & $5.65 \times 10^{5}$ & $9.10 \times 10^{4}$ & 83.89 & $4.95 \times 10^{5}$ & $1.45 \times 10^{4}$ & 99.93 \\
3 & $2.40 \times 10^{8}$ & $7.70 \times 10^{4}$ & 99.97 & $1.16 \times 10^{8}$ & $7.70 \times 10^{4}$ & 99.96 \\
4 & $1.21 \times 10^{8}$ & $5.55 \times 10^{4}$ & 99.95 & $7.07 \times 10^{7}$ & $2.90 \times 10^{4}$ & 99.99 \\
5 & $1.20 \times 10^{8}$ & $4.25 \times 10^{3}$ & 99.99 & $1.10 \times 10^{8}$ & $3.00 \times 10^{3}$ & 99.81 \\
6 & $7.12 \times 10^{6}$ & $1.40 \times 10^{4}$ & 99.80 & $6.12 \times 10^{6}$ & $1.17 \times 10^{4}$ & 99.88 \\
7 & $1.26 \times 10^{9}$ & $7.75 \times 10^{3}$ & 99.99 & $1.50 \times 10^{6}$ & $1.85 \times 10^{3}$ & 99.21 \\
8 & $6.10 \times 10^{6}$ & $7.75 \times 10^{3}$ & 99.87 & $9.70 \times 10^{5}$ & $7.65 \times 10^{3}$ & 94.95 \\
9 & $2.10 \times 10^{5}$ & $6.15 \times 10^{3}$ & 97.07 & $9.70 \times 10^{4}$ & $4.90 \times 10^{3}$ & 98.62 \\
10 & $9.70 \times 10^{5}$ & $1.25 \times 10^{4}$ & 98.71 & $6.70 \times 10^{5}$ & $9.25 \times 10^{3}$ & 99.93 \\
11 & $1.90 \times 10^{6}$ & $3.80 \times 10^{3}$ & 99.80 & $1.65 \times 10^{6}$ & $1.20 \times 10^{3}$ & 99.81 \\
12 & $1.26 \times 10^{9}$ & $7.75 \times 10^{3}$ & 99.99 & $1.11 \times 10^{6}$ & $2.05 \times 10^{3}$ & 99.92 \\
13 & $2.05 \times 10^{6}$ & $1.60 \times 10^{3}$ & 99.92 & $1.70 \times 10^{6}$ & $1.40 \times 10^{3}$ & 99.83 \\
14 & $2.26 \times 10^{7}$ & $2.10 \times 10^{4}$ & 99.91 & $1.01 \times 10^{7}$ & $1.75 \times 10^{4}$ & 99.54 \\
15 & $1.09 \times 10^{7}$ & $6.60 \times 10^{3}$ & 99.94 & $6.55 \times 10^{5}$ & $3.00 \times 10^{3}$ & 99.96 \\
16 & $7.55 \times 10^{7}$ & $3.25 \times 10^{4}$ & 99.96 & $5.05 \times 10^{7}$ & $1.80 \times 10^{4}$ & 99.99 \\
17 & $1.39 \times 10^{8}$ & $1.09 \times 10^{4}$ & 99.99 & $9.40 \times 10^{7}$ & $7.30 \times 10^{3}$ & 99.81 \\
\hline Average & $1.70 \times 10^{6}$ & $2.60 \times 10^{3}$ & 99.85 & $8.00 \times 10^{5}$ & $1.55 \times 10^{3}$ & 99.29 \\
\hline
\end{tabular}

Table 4. Most probable number (MPN $100 \mathrm{~mL}^{-1}$ ) of total and thermotolerant coliforms in the influent, effluent from the digester and in the stabilization pond, and removal rate (\%) in the 18 -week period

\begin{tabular}{ccc}
\hline Sampling point & $\begin{array}{c}\text { Total coliforms } \\
\text { MPN } 100 \mathrm{~mL}^{-1}\end{array}$ & $\begin{array}{c}\text { Thermotolerant coliforms } \\
\text { MPN } 100 \mathrm{~mL}^{-1}\end{array}$ \\
\hline Influent & $1.82 \times 10^{8 \mathrm{a}^{*}}$ & $2.60 \times 10^{7 \mathrm{a}}$ \\
Effluent from biodigester & $4.15 \times 10^{5 \mathrm{~b}}$ & $1.11 \times 10^{5 \mathrm{~b}}$ \\
Effluent in stabiliz. pond & $2.13 \times 10^{4 \mathrm{c}}$ & $1.23 \times 10^{4 \mathrm{c}}$ \\
\hline
\end{tabular}

*Different letters in the same column differ statistically at a probability of 5\%

However, despite the good removal rates of indicator bacteria by the biological treatment used in this study, the removal rate of thermotolerant coliforms $\left(1.49 \times 10^{4}\right)$ did not attain the standard of 4000 MPN $100 \mathrm{~mL}^{-1}$ established by CONAMA Resolution 357 (BRASIL, 2005) for discharge into class 3 freshwater bodies, nor can it be used to irrigate tree, cereal and forage crops. Although Souza et al. (2015) achieved a significant reduction in the number of coliforms, the bacterial populations in the effluent were still too high to allow for its reuse.
Thus, the inclusion of a tertiary treatment of effluents from stabilization ponds should be considered with a view to improving their microbiological quality so as to reach lower counts than those established by current legislation, allowing these effluents to be used at least for the fertigation of tree, cereal and forage crops. Even though Souza et al. (2015) employed more processing steps in their biological system than those used in this study, they pointed out the need for tertiary treatment, such as disinfection by sodium hypochlorite or ultraviolet radiation, in 
order to ensure the removal of a pathogens from the effluent.

Araújo et al. (2015), who used soil as a tertiary treatment after treatment in a system comprising a septic tank and anaerobic filter, found that contaminants were carried through the vertical and horizontal soil profiles, reaching surface water and groundwater. This finding therefore confirms the need for another stage in the system under study in order to minimize the microbiological load of thermotolerant coliforms prior to fertilization, in order to comply with Brazil's legal standards for the reuse or disposal of treated wastewater.

Several studies have reported the influence of HRT on the removal efficiency of total and thermotolerant coliforms in wastewater. Betancur et al. (2016) evaluated continuous flow digesters with HRT ranging from 2 to 7 days and reported that total and thermotolerant coliforms persisted after the treatment. Chen et al. (2012), who evaluated various HRTs of 11,16 and 25 days, observed that the highest $E$. coli removal rate was achieved with HRT of 25 days. In this study, although the same HRT of 25 days was used, the reduction of the microbial load did not reach satisfactory parameters for reuse. Therefore, in addition to considering another step in the treatment, the need for a longer HRT should be evaluated as a means to improve the quality of the effluent.

\section{CONCLUSIONS}

The use of the biological system comprising a continuous flow anaerobic digester and an optional stabilization pond for the treatment of domestic sewage proved to be a good alternative in terms of the reduction of total and thermotolerant coliform bacteria.

The system was efficient in reducing the number of indicator bacteria of fecal contamination, with the complete system reaching overall removal rates of $98.76 \%$ for total coliforms and of $99.29 \%$ for thermotolerant coliforms. However, a tertiary treatment involving polishing should be included to render the effluent suitable for use in fertigation or for discharge into water bodies.

\section{ACKNOWLEDGMENT}

The authors acknowledge CNPq, Brazil's National Council for Scientific and Technological Development, for its financial support of this project.

RESUMO: Aliar tecnologias que sejam viáveis e ainda eficientes em mitigar o impacto gerado pelos resíduos, que possuem potencial patogênico à saúde humana e animal, tem sido o propósito das ações de pesquisadores em todo $o$ mundo. Dessa forma, objetivou-se avaliar um sistema de tratamento biológico, quanto a redução de coliformes totais e coliformes termotolerantes, visando a possibilidade de reciclagem orgânica do esgoto doméstico. Para tanto foi utilizado um biodigestor tubular de fluxo contínuo com tempo de retenção hidráulica (TRH) de 25 dias e uma lagoa de estabilização facultativa, responsável pelo tratamento de esgoto produzido por 150 pessoas, no município de Sertãozinho/SP. As amostras foram colhidas, semanalmente e sempre no mesmo dia, em três pontos distintos de colheita (entrada do sistema de tratamento, saída do biodigestor tubular e na lagoa de estabilização facultativa), totalizando 108 amostras. Para as determinações das populações de coliformes totais e termotolerantes foi utilizada a técnica do NMP em tubos múltiplos série de três tubos (APHA, 2005). O sistema foi eficiente quanto a redução no número de micro-organismos indicadores de poluição fecal atingindo $98,75 \%$ para coliformes totais e $99,26 \%$ para os termotolerantes. Entretanto, deve ser prevista mais uma etapa para polimento do efluente dando condições para sua utilização na fertirrigação ou lançamento em corpos de água.

PALAVRAS CHAVE: Biodigestor anaeróbio fluxo contínuo. Esgoto sanitário. Lagoa de estabilização. Microorganismos indicadores. Sustentabilidade ambiental.

\section{REFERENCES}

APHA; AWWA; WEF. Multiple tube fermentation technique for members of the coliform group. In: Standard Methods for the Examination of Water and Wastewater. $21^{\text {st }}$ ed. Washington DC: APHA, 2005. Section 9221. 
ARAÚJO, R. K.; WOLFF, D. B.; CRUZ, J. C.; BAGGIOTTO, C.; FRIEDRICH, M. Dinâmica das contaminações do solo e água subterrânea por efluente sanitário em área de preservação permanente com macrófitas e gramíneas. Ciência \& Engenharia, v. 24, n. 1, p. 115 - 123, Jan - Jun 2015. http://dx.doi.org/10.14393/19834071.2015.28847

BETANCUR, O. J.; BETANCOURT, J. A.; ESTRADA, J; HENAO, F. J. Persistence of pathogens in liquid pig manure processed in manure tanks and biodigesters. Revista MVZ Córdoba, v. 21, n. 1, p. 5237-5249, 2016. http://dx.doi.org/10.21897/rmvz.33

BMGF (Bill and Melinda Gates Foundation), 2011. Water, sanitation \& hygiene. Strategy overview (2011)

BRASIL. Ministério do Meio Ambiente. CONAMA. Resolução nº 357, de 17 de março de 2005. Dispõe sobre a classificação dos corpos de águas e diretrizes ambientais para o seu enquadramento, bem como estabelece as condições e padrões de lançamento de efluentes, e dá outras providências. Brasília, 2005.

CALIJURI, M. L.; BASTOS, R. K. X.; MAGALHÃES, T. B.; CAPELETE, B. C.; DIAS, E. H. O. Tratamento de esgotos sanitários em sistemas reatores UASB/wetlands construídas de fluxo horizontal: eficiência e estabilidade de remoção de matéria orgânica, sólidos, nutrientes e coliformes. Revista Engenharia Sanitária e Ambiental, v. 14, n. 13, 2009.

CHEN Y, FU B, WANG Y, JIANG Q, LIU H. Reactor performance and bacterial pathogen removal in response to sludge retention time in a mesophilic anaerobic digester treating sewage sludge. Bioresource Technology, v. 106, p. 20-26, 2012. http://dx.doi.org/10.1016/j.biortech.2011.11.093

COLÓN, J.; FORBIS-STOKES, A. A.; DESHUSSES, M. A. Anaerobic digestion of undiluted simulant human excreta for sanitation and energy recovery in less-developed countries. Energy for Sustainable Development. v. 29, p. 57-64, 2015. http://dx.doi.org/10.1016/j.esd.2015.09.005

KINYUA, M. N.; ROWSE, L. E.; ERGAS, S. J. Review of small-scale tubular anaerobic digesters treating livestock waste in the developing world. Renewable and Sustainable Energy Reviews, v. 58, p. 896-910, 2016. http://dx.doi.org/10.1016/j.rser.2015.12.324

MARÍN, I.; GOÑI, P.; LASHERAS, A. M.; ORMAD, M. P. Efficiency of a Spanish wastewater treatment plant for removal potentially pathogens: Characterization of bacteria and protozoa along water and sludge treatment lines. Ecological Engineering, v. 74, p. 28-32, 2015. http://dx.doi.org/10.1016/j.ecoleng.2014.09.027

MOURA, F. N.; BATISTA, R. O.; SILVA, J. B. A.; FEITOSA, A. P.; COSTA, M. S. Desempenho de Sistema para Tratamento e Aproveitamento de Esgoto Doméstico em Áreas Rurais do Semiárido Brasileiro.

Engenharia Ambiental - Espírito Santo do Pinhal, v. 8, n. 1, p. 264-276, 2011.

SOUZA, C. F.; BASTOS, R. G.; GOMES, M. P. M.; PULSCHEN, A. A. Eficiência de estação de tratamento de esgoto doméstico visando reuso agrícola. Revista Ambiente \& Água, v. 10, n. 3, 2015. 